\title{
Apocalypse (Not) Now
}

\author{
Sven Lütticken
}

\begin{abstract}
From its beginning in the 1940s, the nuclear regime has been the subject of aesthetic as well as political practices and interventions. This article examines a number of such interventions, from the Surrealists via the Situationists to the present. The focus is on forms of aesthetic activism that challenges the reigning thanatocracy. Key figures are Roberto Matta and Wolfgang Paalen (as "first responders" in the 1940s), Situationists such as Debord and Vaneigem in the late 1950s and 1960s (effecting a repoliticization of avant-garde aesthetics), later writings by ex-Situationists and pro-Situs such as René Riesel and Jaime Semprun, as well as contemporary artists such as Ei Arakawa and The Otolith Group (and their responses to Fukushima). Through concepts and tropes such as invisibility, survival and mutation, these practitioners seek to counteract the "insensible" nature of radiation and problematize post-war society's dependency on nuclear deterrence and "peaceful" nuclear technology alike.

KEYWORDS Invisibility, Neo-avant-garde, Nuclear arms, Nuclear energy, Radiation
\end{abstract}

Those who today limit themselves to the perception of whatever happens to be visible at that moment miss reality.

-Günther Anders ${ }^{1}$

At a 1984 "Nuclear Criticism" conference, Jacques Derrida gave a lecture titled "No Apocalypse: Not Now," in which he argued that a nuclear "apocalypse" would actually not be worthy of that name. The very distinction between science and belief has collapsed in the age of Cold War rhetoric. Nuclear power being no longer strictly techno-scientific but rather "techno-militaro-politico-diplomatic," its calculations are as it were polluted with "doxa, opinion, 'belief."' 2 This also means that there is no longer any place for truth: "No truth, no apocalypse. (As you know. Apocalypse means Revelation, of Truth, Un-veiling.)"3 With a nuclear catastrophe, there can be no Hegelian, teleological end of history, with Spirit finally realizing its essence.

What nuclear technology does announce is the possibility of a total destruction of the cultural archive, much more radical than that of the Library of Alexandria. ${ }^{4}$ Even while we thus appear to face the destruction of literature and culture by technoscience, Derrida argues that nuclear technology is itself "fabulously textual," being built upon structures of information, structures of language, and nuclear war existing only as a myth or fantasy: 
For the moment, today, one may say that a non-localizable nuclear war has not occurred; it has existence only through what is said of it, only where it is talked about. Some might call it a fable, then, a pure invention: in the sense in which it is said that a myth, an image, a fiction, a utopia, a rhetorical figure, a fantasy, a phantasm, are inventions. It may also be called a speculation, even a fabulous specularization. The breaking of the mirror would be, finally, through an act of language, the very occurrence of a nuclear war. Who can swear that our unconscious is not expecting this? Dreaming of it, desiring it? ${ }^{5}$

As the field of fantasy and belief, as fabulously textual, the nuclear regime has from its beginning been the subject of aesthetic as well as activist practices and interventions. However, certain of these practices can also be seen as de facto critiques of Derrida's insistence on the textual and the fantasmatic, on text and image. Does the nuclear regime not exacerbate the crisis of the aesthetic? Or, to put it differently: does it not intensify the aesthetic as a practice and theory of crisis? The aesthetic pertains to the senses, to the sensible. What, then, if the modern "mastery" of matter penetrates the infra-sensible realm, with consequences for all living beings that are carefully kept abstract and hypothetical?

\section{First Responses}

The avant-garde had a profound investment in realities below the threshold of visibility - and with operations that would introduce them into the visual by changing the nature of the image. Moholy-Nagy's "new vision" and Walter Benjamin's "optical unconscious" are cases in point. Film and photography were credited with the power to make the world manifest itself in unprecedented ways, beyond 19th century realism, and beyond the capabilities of the human eye. Moholy's interest in X-rays and Benjamin's in psychoanalysis are far from disconnected to their investment in the possibilities of film: Akira Azura Lippit has argued that psychoanalysis, X-ray and cinema, all developed or discovered around the same time, were the essential techniques of "avisuality" of the early twentieth century, promising to make things and the mind transparent. ${ }^{6}$

In "Prolégomènes à un troisième manifeste du Surréalisme ou non," which was published in $V V V$ in New York in 1942, André Breton launched the "new myth" of the "Great Transparent Ones" - giant invisible beings whose parasites we humans are. The text was illustrated by Roberto Matta, who always maintained that he had provided Breton with the idea for the Grands Transparents. ${ }^{7}$ Whereas Breton interpreted them more literally as enormous invisible beings, for Matta they were 
wave-forms: "That's what had interested Breton, the idea of 'great transparencies' that I spoke about. The great transparencies in these paintings were like waves - they were, for example, economic, social, and political upheavals." ${ }^{8}$ To this list, one surely has to add nuclear events. Shortly after WWII, Matta illustrated Denis de Rougememont's book Lettres sur la bombe atomique, published by Brentano's in New York. As the introduction states, Matta "was always drawn to modern physicists' work on wave propagation and radiation, and to the huge transformations that scientists had imposed on matter" - with drawings of emaciated beings in some non-Euclidian forcefield. ${ }^{9}$ However, his illustrations for de Rougemont's book reflect an anthropomorphic turn in his work, characterized by emaciated figures Matta often referred to with the term vitreur. These vitreurs inhabit the universe of the Grands Transparents.

De Rougemont, a Swiss author who was to become one of the mainstays of the CIA-backed Congress for Cultural Freedom, reports in his book on the last months of 1945, which he spent on the American East Coast, where he encountered two cultures: that of art, as exemplified by Marcel Duchamp, and that of (nuclear) science. Duchamp, identified here only (and rather misleadingly) as "a surrealist painter," did not let the explosion of the first nuclear bombs change his convictions: science is nothing but a mythology, its "laws" are man-made myths and have no bearing on reality. The explosion of the Bomb did not prove that science had actually penetrated the core of reality: "Some proof - they had arranged for it!"10 During a stay in Princeton, de Rougemont found himself surrounded by the scientists who had "arranged" the explosion; here Einstein - the Moses of the atomic Earth - walked by his window. For de Rougemont, the Bomb heralded the end of war and contained "possibilities for a global union." ${ }^{11}$ What was needed in the face of global nuclear annihilation was a "planetary thinking": "To the planetary weapon thus corresponds a universal community that relegates nations to the status of mere provinces. Let yourself get carried away for a moment in this revolving game of symbols: the Earth, the Globe, the Ball, the Head, the Bomb, and the Unit regarded always and everywhere as a round object apple, sphere or golden scepter, whether the Universe, or the Empire, or the Atom. Here, extremes mirror each other."12 As many science-fiction films would reiterate, it takes a planetary threat to create global unity.

During the late 1930 s and early 1940s, advances in particle physics seemed to be full of promise to some of the younger Surrealists: was this not an exemplary science that was both materialist and sur-real, promising new ways of understanding and altering reality? Wolfgang Paalen, 
who lived and worked in Mexico during World War II, having broken with Breton's group, claimed in a 1944 interview: "It seems to me that we have to reach a potential concept of reality, based as much on the new directives of physics as on those of art."13 Having liberated himself from Breton, Paalen embarked on a crusade against dialectics, reserving special scorn for Engels's notion of a dialectic of nature, which made the category mistake of applying logical categories not only to history, but even to the natural world. ${ }^{14}$

But while Paalen attacked Engels's famous law of the transformation of quantity into quality as nonsense, he effectively presented his own version of surrealist dialectics by arguing that "[the] new Quantum Physics is compelled to abandon the rigorous determinism that until now was held to be the very foundation of physics," and therefore compelled to question physics' "pretension of offering us a purely quantitative and yet satisfying interpretation." ${ }^{15}$ This in turn had to have consequences for art as the domain of qualitative experience, albeit one that had often been made subject to pictorial rules and "laws." As Paalen phrased the relation between advanced science and advanced art: "Quantitative physics, in perceiving that the causal concept becomes inapplicable in the microscopic domain - and painting, in abandoning the causal development of plastic relations - is the same revolution."16 The "new physics" having abandoned causality and certitude for potentiality and possibility, Paalen adopted the Greek term dynaton (the possible) for his art. Abbreviated to Dyn, this became the name of the journal he published from Mexico - in part to remain a presence in the New York art world.

Matta's characterization of Paalen as "the first painter of the Atomic Age" irked the latter, who complained about it in a letter written a few weeks after the Hiroshima and Nagasaki bombings. ${ }^{17}$ To Paalen, it seemed that Matta was compromising his work by placing it in an illustrative relation with Hiroshima and Nagasaki - which is what Matta did with his own work in illustrating de Rougemont's book..$^{18}$ Paalen, in turn, did respond quite directly to the double nuclear event of August 1946 with a play he completed the following year, The Beam of the Balance. In a post-Hiroshima counterpoint to his earlier praise for the new physics, Paalen's play is a sci-fi allegory on the dangers of nuclear power in the hands of all-too-human scientists and barely human politicians. As Paalen notes in the "Brief Outline" for his play, "Reality has, at last, become big enough to do away with realism. [...] The incommensurable explosions of 1945 have not only smashed cities but also shattered consciences. The same men who have been able to release forces beyond the 
dreams of yesterday, have proved inadequate to tell us what to do with these forces." ${ }^{19}$

Convinced that only an artistic "liberation of the imagination" can result in the "broadening of vision: necessary to deal with the new (un) reality," Paalen opens his three-act play with a cosmic vision set among the stars: "Cosmogons," great cosmic forces, watch stars and/or planets (Paalen seems not to care about the distinction) blow up one after another, as civilizations develop technologies they cannot control. Earth, we hear, still hands in the balance - there is a "decisive struggle" going on, and in the three acts to follow we witness that struggle, involving a scientist (Prometheus/Faust), an ape-like, brutish dictator whose name (Gori) is a reference to Stalin's birthplace, and a stand-in for Paalen himself, Frank. The first two acts are set in a post-office that is crumbling under the unleashed power of "anagravity," which has been unlocked by Prometheus/Faust and stolen by Gori - and which is Paalen's stand-in for nuclear power. In the third act, Prometheus and Frank return to a postapocalyptic earth, having absconded with a spaceship when things went really wrong; they find a wasteland, but Gori is still alive and unchanged. Disappointed with Marxism and with Surrealism, Paalen retreats to a position of bourgeois humanism. The resulting critique of human folly is prevented from being truly withering by its general and abstract nature.

A reading of The Beam of the Balance took place at Robert Motherwell's house; the year before, Motherwell had published a collection of Paalen's writings, Form and Sense.${ }^{20}$ Motherwell's fellow post-Surrealist, Barnett Newman, saw in Hiroshima the need for a new tragic culture. In his essay "The New Sense of Fate" (1948), Newman praised Greek tragic poetry to the detriment of Greek visual art (sculpture), which had no real sense of tragedy and was focused on physical beauty. Newman noted that after WWII, the artist "has more feeling and consequently more understanding for a Marquesas islands fetish than for the Greek figure." ${ }^{21}$ The war was the gruesome realization of Surrealism, making much Surrealist art look very recherché and aesthetic in the process:

The war the Surrealists predicted has robbed us of our hidden terror, as terror can exist only if the forces of tragedy are unknown. We now know the terror to expect. Hiroshima showed it to us. We are no longer, then, in the face of a mystery. After all, wasn't it an American boy who did it? The terror has indeed become as real as life. What we have now is a tragic rather than a terrifying situation. $^{22}$

In 1945, Georges Henein, member of an Egyptian Surrealist group, re- 
sponded to Hiroshima in an essay titled "The Prestige of Terror." Praising "the valiantly independent attitude of Camus - and, for other things, of a Breton, a Calas, a Rougemont," Henein develops a much more political analysis of "terror" than Newman with his "tragic" stance. ${ }^{23}$ After Auschwitz, carpet bombings and Hiroshima, the Dialectic of Enlightenment had finally culminated in a generalized system of terror and counterterror that seemed to offer a form of security: "Today, a new generation of Encyclopédists who proceeded with the same impertinence as the earlier one, would be made illegal or quickly reduced to begging. Everything is taking place as if man were looking into this long series of unhappy ambitions for a certain form of security in the terror." ${ }^{24}$ This kind of dialectical analysis of post-war "security in terror" was far removed from Newman's concerns, which were couched in much more abstract-existential terms. In his conclusion, Newman asks and asserts: "shall we artists make the same error as the Greek sculptors and play with an art of overrefinement, an art of quality, of sensibility, of beauty? Let us rather, like the Greek writers, tear the tragedy to shreds." ${ }^{25}$

While there are notable exceptions, especially in literature and the cinema, on the whole the art of the "first responders" of the late 1940 s and 1950 s tended to stage the post-war nuclear age as existential tragedy rather than as political issue. ${ }^{26}$ To a large extent this is true also of the arte nucleare movement created in $1950-51$ by Enrico Baj and others. Their pronouncements on the destruction of existing forms and isms and on the "tragic" condition of man in the nuclear age remain within the horizon of post-war "nuclear existentialism," and Baj's attempts to create pictorial equivalents for this condition are fully part of the family of post-Matta and post-Paalen art informel - though there are striking exceptions, such as the $195^{2}$ Manifesto Bum painting, with the text painted over a blotched nuclear cloud. ${ }^{27}$

The aesthetic-existentialist "nuclear art" of the first ten post-war years was profoundly humanist so far as it ultimately posited the artwork as fragile yet enduring in opposition to what Derrida would articulate as "the possibility of an irreversible destruction, leaving no traces, of the juridico-literary archive" - or indeed of the cultural archive in general. The possibility of a total and remainderless destruction of culture and of life is evoked yet at the same time symbolically conquered through the proliferation of tattered, ravaged or starkly simplified and thereby sublime and existential forms.

In 1958, during an anti-nuclear conference in Tokyo, the philosopher and anti-nuclear activist Günther Anders visited the memorial of the 
nuclear bombardment in Hiroshima. Its abstract arch only appeared symbolic "because the non-functional always suggests symbolism," and reminded him of American abstract expressionism and its endorsement by the US, even by the War Department itself: ${ }^{28}$

It is no coincidence that this belated official preference for the destruction of figurative forms in art (the propaganda for enjoyment of this destruction and the mocking of those who did not go along with this artistic progress) occurred simultaneously with the actual destruction of the world; nor is it a coincidence that the dress rehearsal for this destruction, which occurred in Hiroshima, found its memorial in a "non-objective object."29

Anders's unwillingness to see in Abstract Expressionism anything but a politically motivated rip-off of pre-war European modernism is obviously problematical, but his suspicions of the open, non-committal nature of the pseudo-symbolism of such art are worth pondering.

This openness contributed to the aesthetic success of post-war abstraction, but also condemned its attempts to respond to the new nuclear era to the production of pat and hollow sub-existentialist suggestions. If, to use a phrase by Sabu Kosho that also evokes Jean-Luc Nancy's analysis of the "equivalence of catastrophes," nuclear explosions and disasters announce "the advent of an age when commodification of everything by capitalism has reached the point where general equivalence of value is increasingly approaching the proximity of general catastrophe of living," then the art in question tacitly ascribes to this equivalence - and inscribes itself into it. ${ }^{30}$ The equivalence of the value of all life in the equivalence of (potential) catastrophes is aestheticized in the form of cultural commodities that are anxiously, tormentedly at home in the global thanatocracy of the nuclear regime. ${ }^{31}$

In 1958, when Anders visited Hiroshima, the first anti-nuclear movement was gaining traction. In Britain, the Campaign for Nuclear Disarmament (CND) was launched, and with it the New Left. More marginally, in Paris André Breton penned an anti-nuclear manifesto, Demasquez les physiciens, videz les laboratoires, which was co-signed mostly by younger Surrealists, and which attacked the "theology of the bomb" and science's status as the new "Opium of the People." 32 While the text exhorts the reader to support a Comité de Lutte Anti-Nucléaire, this does not appear to have gained any traction. Nonetheless, this tract is a sign of things to come: the neo-avant-garde would go on to desublimate the nuclear aesthetics of the post-war era. 


\section{Every Day Is like Survival}

The fact that I critique a problematic aestheticization of the nuclear should not be taken to mean that I wish to install an undialectical dichotomy of "merely aesthetic" and "properly political" responses. The problem is perhaps not that the aforementioned responses are aesthetic, but that they are all too exclusively artistic, which curtails their aesthetic potential. In Hans Magnus Enzenberger's words, it is a matter of pursuing “an aesthetic which is not limited to the sphere of 'the artistic."'33 When Karl Marx predicted (or demanded) that under Communism painters, people exclusively devoted to the profession of painting, would be replaced by people who also paint, he was announcing the transformation of work as the aesthetic project par excellence. ${ }^{34}$

Like "culture," the "aesthetic" is a wider category than art. The modern aesthetic régime, or the modern ideology of the aesthetic, conceptualizes art both (variously, and sometimes simultaneously) as a realm of sensuous plenitude and as impoverished and locked up in failed forms and institutional structures. If aesthetic theory was to become primarily a philosophy of art, it could never shake off the wider remit given to the aesthetic by Baumgarten and Kant, as pertaining to the world of the sense or to the beautiful as such. Following Schiller, "aesthetic education" always came with a suspicion towards art. To fully realize art, it needed to overcome its limitations and realize itself in life, socially. This is the program that Schiller and early German Romanticism would bequeath to the avant-garde.

However, German Romanticism also saw a new emphasis on the essential national characteristics of the art of each people, separating it from that of other nations. "Kultur or Culture [...] became the name of the Romantic, pre-Marxist critique of early industrial capitalism." ${ }^{35}$ Kultur was the name for a conservative version of the aesthetic revolution, of the dream of the integration of art into life and of overcoming art's newly asserted but already crippling autonomy. Kultur connected art to the people. Just as the Wilhelmine Empire would construct a parliament and dedicate it to "Dem deutschen Volke," so there would be a Nationalgalerie dedicated to "Der deutschen Kunst."

However, conservative-romantic programmes were less distinct from modern mass media and entertainment than their authors would have liked. ${ }^{36}$ Bayreuth may have been a temple for the German Volk and its art, but the grail lights up electrically like a product at a world's fair or department store. ${ }^{37}$ Kultur becomes a global capitalist Kulturindustrie, which confronts the "aesthetic revolution" of modern art with its obscene 
double: the Aufhebung of art takes the form of commodified leisure and lifestyle. Rather than organically emerging from the people, as per conservative-romantic aesthetics, culture is mass-produced by experts. As Carl Andre, one of the protagonists of the Art Workers Coalition in the late 1960s, famously put it: "Art is what we do. Culture is what is done to us." ${ }^{38}$ Artist have indeed been "separated from culture," with the latter appearing like an alien structure imposed by distant boardrooms.

When the Situationist International called for a cultural revolution in the late 1950s, this was part of its attack on "autonomous" art as well as on the cultural industry. ${ }^{39}$ Art and "mass culture" alike were exponents of the spectacle; in fact, art has already been abolished by being integrated in spectacular culture. Given the "cultural turn" of capitalism in the advanced society of the spectacle, what was needed was not "just" a political or even social revolution, but a full-blown cultural revolution that would entail the aesthetic transformation of life - not as a substitute for its socio-political transformation, but as its culmination. In the early 6os, at a time of escalating nuclear tensions, this was often cast in terms of a fight of life against mere survival in the nuclear society of the spectacle. The 1962 article "The Geopolitics of Hibernation" in the Internationale Situationniste journal mentions the famed "Doomsday system," which two years later would feature as non-human antagonist in Kubrick's Dr. Strangelove: "one extremist faction of American defense doctrine has gone so far as to argue that 'the best deterrent would consist of the possession of an enormous thermonuclear bomb buried underground. If the enemy attacked, the bomb would be detonated and the Earth would be blown apart."'40

Taking up Raoul Vaneigem's claim that life was increasingly being reduced to mere survival (which is, in fact, life's opposite), the article argues that:

The theorists of this "Doomsday System" have certainly found the ultimate weapon for enforcing submission; they have for the first time translated the refusal of history into precise technical powers. But the rigid logic of these doctrinaires only responds to one aspect of the contradictory needs of the society of alienation, whose indissoluble project is to prevent people from living while it organizes their survival (see the opposition of the concepts of life and survival described by Vaneigem in Basic Banalities). Thus the Doomsday System, through its contempt for survival - which is still the indispensable condition for the present and future exploitation of human labor - can only play the role of last resort for the ruling bureaucracies: the insane proof of their seriousness. 
But in order to be fully effective in reinforcing people's submission, the spectacle of a war to come must henceforth extend its sway over the organization of our present peacetime existence, while simultaneously accommodating itself to the basic requirements of that organization. ${ }^{41}$

The text homes in on a particularly grotesque manifestation of the nuclear regime: the development of small fallout shelters for the consumer market. These shelters, the Situationists note, will obviously not offer real protection in the case of nuclear war, but protection was only a pretext used to integrate people ever more tightly into a social-economical order that depends on their renunciation of their real desires and their channeling into artificial needs. ${ }^{42}$ Survival as the opposite of and as substitute for life should not, however, be equated with the threat of nuclear war and the fallout-shelter racket:

Survival as the opposite of life, if rarely voted for so clearly as by the buyers of shelters in 1961, can be found at all levels of the struggle against alienation. It is found in the old conception of art, which stressed survival through one's works, an admission of a renunciation of life - art as excuse and consolation (principally since the bourgeois era of aesthetics, that secular substitute for the religious otherworld). ${ }^{43}$

Art, then, had been a de facto fallout shelter of the bourgeois soul long before Hiroshima.

And what about new conceptions of art? The Situationist International was of course torn over the issue of art; did the dépassement of bourgeois art necessitate the abandonment of art making altogether, in anticipation of a future lived art of constructed situations? With the resignation of Jorn in 1961 and the exclusion of the "Nashists" and "Spurists" in 1962, the SI was under the control of the Debordian "anti-art" fraction. This Debordian SI did however organize an art exhibition of sorts in Odense in 1963 - and it was an anti-nuclear show, Destruction of RSG-6. The (by now) opaque title refers to the plans for the British "Regional Seat of Government \#6" nuclear bomb shelter, which had been made public by the group Spies for Peace in April 1962. Picking up the analysis from the previous year, Debord in his text "The Situationists and the New Forms of Action in Politics and Art," which accompanied the exhibition, noted that "It is [...] the universally maintained threat of a nuclear war which now, in both the East and the West, serves to keep the masses submissive, to organize shelters for state power, and to reinforce the psychological and material defenses of the ruling class's power." ${ }^{44}$ 
In what is probably also a tactical response to the success of "artistic" or "Nashist" Situationism in Scandinavia, Debord states that "In the short term [...] a critical art can be carried out within the existing means of cultural expression, from cinema to painting - even though we ultimately wish to destroy this entire artistic framework." ${ }^{45}$ The RSG-6 "event" (as Debord calls it) took the form of a gallery show that combined a space mimicking a fallout shelter and a shooting range with politicians' heads as targets with J. V. Martin's "thermonuclear maps." ${ }^{46}$ Debord noted that "The medium here used in a critical fashion is painting." ${ }^{77}$ Specifically, these paintings mockingly mimic abstract expressionism or art informel, turning their paint structures into war-ravaged landscapes; a nuclear desublimation of "existential" abstract expressionism.

A parallel attempt to turn art into a critical spectacle of destruction, to foreground the political and technological connotations of post-war art's "destruction of form" can be found in Gustav Metzger's "Auto-Destructive Art." In 1960, Metzger wrote: "Man in Regent Street is auto-destructive. Rockets, nuclear weapons, are auto-destructive. [...] The drop drop dropping of $\mathrm{HH}$ bombs. [...] Auto-destructive art re-enacts the obsession with destruction, the pummeling to which individuals and masses are subjected." ${ }^{48}$ However, by Situationist standards Metzger's auto-destructive art remained too heavily invested in artistic gestures, with his treatment of nylon canvases with aggressive acids becoming an Yves Kleinlike show. The "didactic" exhibition in Odense notwithstanding, the SI was wary of "re-enacting the obsession with destruction," which could all too easily become a symbolic substitute for action within the framework of art, or of mainstream popular spectacle - as in Pete Townsend's theatrical guitar-smashing.

The SI tended to use media that could be used for incursion and insertions into various contexts, without becoming fully part of them: books and pamphlets, detourned comic strips, posters and postcards, various forms of agitation and direct action. As is evident from this list, lateGutenbergian Print culture in various manifestations was obviously key. The nexus of "socialism and print" went through its last great cycle in the 1960 and early 1970 os. ${ }^{49}$ Film was of course another crucial medium for the Situationists, but Debord's films or René Viénet's Can Dialectics Break Bricks (1972) "detourned" existing films precisely in order to counter the scopic and fetishistic lure of such spectacles. ${ }^{50}$ In Britain in the 1960s, a filmmaker with access to the BBC's means of production made a television programme that détourned not actual pre-existing film footage, but rather various conventions of TV reportage and cinéma vérité as 
well as mainstream filmmaking. Peter Watkins's The War Game (1965), which the BBC refused to air for decades, showed a "pre-enactment" of a nuclear attack striking Britain in what often looks uncannily like actual newsreel footage, even though the voice-over emphasizes that this is a hypothetical scenario on the basis of currently available data; this is how a nuclear war would likely play out. The footage focusing on the daily (and soon not-so-everyday) lives of ordinary people suggests documentary presentness, and it is probably the strength of this suggestion that made the BBC lock away Watkins's film. Similar to Situationists film, the voice-over and intertitles are didactic and create a dialectical tension with the images, but in Watkins's case the images are already a counterspectacle that shows what cannot - what must not - be represented.

After the film version of La Société du spectacle in 1973 and a short film on its critical reception in 1975, Debord made In girum imus nocte et consumimur igni (1978) as his farewell to the cinema. The film's producer, Gérard Lebovici, was also the patron of the publishing house Champ Libre (later Éditions Gérard Lebovici, later still Éditions Ivrea), with which Debord was closely involved - functioning as an éminence grise behind the scenes. ${ }^{51}$ For almost two decades, this small and close-knit organization played a central role in his actitivities. Champ Libre was defiantly classicist in its book design and from a certain point refused to send newspapers review copies. Champ Libre was an autonomist organization that sought to maintain its own cultural-revolutionary activity in the face of the counter-revolutionary appropriation of May 68. The nuclear question was put squarely on the publisher's post-Situationist agenda with the Chernobyl disaster in 1986.

From the early seventies through the 1980s, a wide-ranging movement, or constellation of movements, against military as well as "peaceful" nuclear power had of course developed, with the emergence of the Green Movement and the early 1980 s protests against the stationing of cruise missiles in Europe. Debord and other ex-Situationists were largely absent from these "new forms of action." The nuclear question became an issue in Champ Libre circles largely because of Jaime Semprun, who in 1980 published a book on the "nuclearisation of the world," which takes the ironic form of a "modest proposal" supposedly written by a rabid defender of the nuclear regime. Semprun became a stalwart of Debord's/Champ Libre's circle, and after the Chernobyl disaster in 1986 Éditions Gérard Lebovici (as Champ Libre had been renamed after Lebovici's assassination in 1984) published a reprint of La Nucléarisation du monde. The book now bore Semprun's name; it had originally been anonymous. ${ }^{52}$ 
The following year, Éditions Gérard Lebovici published an anonymous book that responded explicitly to the Chernobyl disaster, Anatomie d'un nuage (Anatomy of a Cloud)..$^{53}$ Authored by Jean-Pierre Baudet, who imitated many of Debord's trademark tics, such as references to Clausewitz (whose writings he translated for Lebovici), the pamphlet argued that it is a fatal mistake to differentiate between military and civilian or "peaceful" uses of nuclear energy; it is in both cases a matter of warfare, of war against the global population in the service of a world-economical system that perpetuates itself at all costs. ${ }^{54}$ Baudet was part of the editorial group of Jaime Semprun's Encyclopédie des nuisances, on which Debord also collaborated. However, due to Baudet's attempts to interest Debord in Günther Anders's 1950s anti-nuclear classic The Obsolescence of Man, the alliance ended in acrimony (as most of Debord's alliances tended to end) in $1988 .{ }^{55}$

In 2008, Semprun's own Éditions de l'Encyclopédie des nuisances released a book he co-authored with former Situationist René Riesel, Catastrophisme, administration du désastre et soumission durable, which forty years after 1968 delivered a totalizing post-Situationist indictment of the nuclear regime, and of "disaster capitalism" in general. ${ }^{56}$ Parodying Debord's famous opening line, "In societies where modern conditions of production prevail, life is presented as an immense accumulation of spectacle," Riesel and Semprun state that "the whole life of world industrial society now presents itself as an immense accumulation of catastrophes." ${ }^{57}$ The authors effectively present these catastrophes as the dominant form of the spectacle today: "propaganda advocating authoritarian measures." 58

The whole Debordian Champ Libre culture was "fabulously textual." In general, from the early campaigns against survival and nuclear fallout shelters to Chernobyl and beyond, the SI and Debord's post-SI circle write against the spectacle of destruction and survival; they marshal a Gutenbergian culture of radical printing against a different textual culture of nuclear codes, protocols and propaganda. If modern art in general was marked by a fraught dialectic of the specific and the general, of modernist fetishization of specific artistic media on the one hand and romantic and avant-garde attempts to combine, blend and synthesize them into "art" in general on the other, then the nuclear exacerbates this structural crisis of mediality and the senses. As Adorno argues, the divergent developments of different media are related to a historically grown division of labour between different senses, which cannot be wished away. ${ }^{59}$ But to what extent is the nuclear "sensible" at all? Its dangers can certainly be argued in writing, in the abstract and conceptual medium of language - but is this enough? 


\section{Waves of Mut(il)ation}

In Catastrophisme, Riesel and Semprun argue that "Günther Anders' theory of the 'world-laboratory,' according to which the 'laboratory' became co-extensive with the planet at the time of the first nuclear tests, has been positively recuperated, without any rebellious or critical intention whatsoever: as bland confirmation of our confinement in the $e^{x}$ perimental protocol of industrial society." ${ }^{60}$ There are a number of artistic engagements with this "world laboratory." After surrealist-existentialist responses and Situationist critique, one could label this the "third wave" of reaction to the coming of the nuclear age: that of ambiguous artistic experiments in the world laboratory.

An extreme proposal for such an experiment is Henry Flynt's manifesto "Overthrow the Human Race!" presumed to be from 1969, in which the author proposes to induce a thermonuclear war to cause mutations and thereby go beyond the human race. ${ }^{61}$ Flynt's modest proposal radicalizes the motif of mutation in 1950 s and 1960 s sci-fi, from the X-Men to its metaphorical use in Leslie Fiedler's notorious 1965 essay "The New Mutants," which analyses the changing habitus of young Americans in the age of counter-culture and sexual revolution in terms of mutations. ${ }^{62}$ If Flynt presented nuclear mutation as a pseudo-Nietzschean tool to overcome "man," throughout the Cold War (and beyond) mutation was of course most commonly seen as a fearful prospect. Mutation fantasies figures heavily in apocalyptic phantasms, both in fiction and in political discourse. In Holland, for instance, the ecological Kabouter movement that emerged from the ashes of Provo in the late 1960s painted a grim picture of impending monstrous mutations.

The Provo movement of 1965-67 took cues from Constant's New Babylon and did much to galvanize student and youth protest across Europe and beyond - while predictably being attacked by the SI as an insidious form of "recuperation." ${ }^{13}$ Post-Provo, the Kabouter (Gnome or Elf) movement, which pronounced Amsterdam a Kabouter commune in 1969, made ecology one of its key concerns. Protagonist Roel van Duyn argued that the mere collectivization of the means of production was insufficient; they needed to be transformed, beginning with energy: no nuclear energy, but high-tech windmills. ${ }^{64}$ In 1971, Van Duyn \& Co. rang the alarm bell over the production of nerve gas by Philips-Duphar in the sleepy Dutch town of Weesp, which - they feared - messed with the genetic make-up of the insects in the region. In a Kabouter publication, Hans Korteweg and Roel van Duyn quoting an anonymous PhilipsDuphar employee who sketches a possible scenario for the near future: 
Apocalypse (Not) Now

This means that most insects in the area are sterilized - and according to someone from the PR department, Philips Duphar will use this as a selling point in its advertising - , but what is hidden from the public is the fear that many insects will undergo mutations. Just imagine! Wasps with a diameter of $40 \mathrm{~cm}$ who will attack little children in the streets! Butterflies who will only feed on blood protoplasm! $!^{65}$

\section{L'imagination au pouvoir!}

Riesel and Semprun would no doubt consider this to be highly dubious catastrophism - although La Nucléarisation du monde hints at coming mutations that will make humans feel "like a fish in the water of Minimata." ${ }^{\prime 66}$ As Semprun and Riesel emphasize, the "old schema" according to which "if the masses knew, if the truth was not hidden from them, they would revolt," needs to be questioned. ${ }^{67}$ There is, they suggest, "a refusal to understand despite the evidence; or at least to behave, in spite of all the evidence, as if they did not understand." 68 They once more invoke Chernobyl; examples post-dating their text that could be added are the non-response to the Snowden leaks ("I have nothing to hide, so this doesn't concern me") and the Fukushima disaster. While Fukushima, like Chernobyl in its day, did spark a strong resurgence of anti-nuclear protest in Japan and elsewhere, the roll back is already well underway.

As Semprun notes ironically in his La Nucléarisation du monde, "nothing is more discreet than radiation." ${ }^{19}$ As an infra-sensible phenomenon that can, however, result in very visible physical consequences, the nuclear is an aesthetic-political problem. In The Radiant (2012), The Otolith Group investigates the wake of Fukushima though a sonimage that makes audible and visible radiation and its effects - for instance through the sounds of Geiger counters and avant-garde sonic performances, and through luminous images of nocturnal Tokyo. The Radiant engages with the fatal logic of Japanese necropolitics even - and perhaps especially - in those beautiful shots: after all, the city's spectacular radiance is dependent on the dark glow of nuclear radiation. The bright lights of the big city represent the lure of the nuclear regime; this is the hypervisible obverse of the malignant waves that have now made part of Japan uninhabitable.

Throughout The Radiant, the film hovers around the edge of visibility, suggesting a partial transmutation of the infra-sensible into the photosensitive. A sequence that was inspired by a video by Sean Snyder shows a photo camera being patiently disassembled. Musing on how Japanese traditions conceive of the landscape as traversed by wind as well as by spirits, the photographer speculates on the addition of a "new kind of 
invisibility" after Fukushima. The camera may well have to be retooled for a new form of "spirit photography" to come to terms with radiation.

As The Otolith Group's Kodwo Eshun has put it, The Radiant tests "mythologies of radiation" against an actual event, against a reality. ${ }^{70}$ The film repeatedly references anime and popular fantasies of mutation, for instance in a shot of a lounge with monitors on which we see the mythical mutants of anime. In the context of Fukushima, these beings are suggestive of the systemic incapability of Japanese society to abandon nuclear energy. Better to change biology than the economy. In Japan as in the US, the post-war era saw a proliferation of both superheroes and monsters whose existence was in many cases - from Spiderman to Godzilla - explained by references to radiation. For the photographer in The Radiant, the traditional gods inhabiting the landscape and radiation are two conflicting forms of invisibility. Will radiation ever be turned into a god? Under what circumstances could that happen? The new gods of anime and manga seem to be one answer to that question.

In La nucléarisation du monde, Semprun's persona asks if the invisibility on which the nuclear regime depends is not the ultimate, "autonomous" manifestation of "this limitless social power that is the existence of commodified relations." ${ }^{11}$ If the commodity fetish depends on the concealment of labour, then does it not, in the nuclear age, also depend on a concealment of the dead, anorganic labour of nuclear power? And, conversely, does the nuclear regime not depend on willing submission to the mechanisms of commodity fetishism?

Commodity fetishism depends, in Stewart Martin's words, on the "illusion of the commodity's sensuousness. The illusion is 'seen through' by knowing that value is not sensuous, but abstract, a quantum of abstract labour time. But seeing through it does not dissolve it, since it is generated by the social relations of private labour." ${ }^{12}$ This is why just substituting "alternative energies" for the nuclear and leaving everything else in place will not work; under present conditions, such alternatives must remain weak and inadequate substitutes. Just "making visible" is indeed insufficient as long as the social relations that are enabled (or coproduced) by the nuclear regime remain in place.

Some go the other way and exacerbate or emphasize the production of invisibility: the project "Don't Follow the Wind" is an "inaccessible exhibition" in the contaminated zone at Fukushima; the show will remain invisible unless the area is cleared. ${ }^{73}$ The risk of such a gesture is that it might become complicit with a new cult of inaccessibility, of nuclear taboos, of condemned zones. Beyond the Scylla of impotent unveilings 
and the Charybdis of fetishizing invisibility, however, there are ways of making sensible that go beyond the standard critical unveiling of hidden wrongs.

In 2012, Ei Arakawa and the "Green Tea Gallery" (with Stefan Tcherepnin and Hanna Törnudd) made a contribution to the Studium Generale of the Rietveld Academy in Amsterdam that included an exercise in atomic cuisine: For Yum Yum Vibe, Arakawa \& Co. passed around a parcel containing radishes his mother had sent him from the Fukushima region, where she lives. Subsequently, Arakawa and his associates prepared soup from these vegetables. ${ }^{74}$ In 2014, Arakawa repeated the exercise together with his brother in the context of the Frieze Art Fair, now titled Does This Soup Taste Ambivalent ${ }^{75}$

The Amsterdam performance was strongly condemned as irresponsible by some. Sabu Kohso, who was participating in the same programme, strongly cautioned against eating the soup, while a Dutch anti-nuclear activist considered the radiation to be below the critical level. ${ }^{76}$ The piece had the great virtue of making the nuclear sensible, and of foregrounding the attendees' willing or unwilling, witting or unwitting implication in the nuclear economy. Briefly, the nuclear regime became more than fabulously textual or spectacularly invisible. In the middle of an ongoing disaster that refuses to be a real apocalypse, as massive lobbying efforts are undertaken to push a new generation of "safe" nuclear plants, the piece made the nuclear all too tangible.

\section{Notes}

1. "We sich heute auf die Wahrnehmung dessen beschränkt, was der Augenblick gerade an Sichtbarem bietet, der verfehlt die Realität." Günther Anders, "Tagebuch aus Hiroshima und Nagasaki" (1958) in Hiroshima ist überall (Beck: Munich, 1982), p.48. Translation by the author.

2. Jacques Derrida, "No Apocalypse, Not Now (Full Speed Ahead, Seven Missiles, Seven Missives)," Diacritics 14, no. 2 (Summer 1984), pp. 20-31 (p. 24). Sean Snyder appropriated Derrida's title for his exhibition at the Kölnischer Kunstverein in 2013.

3. Derrida, "No Apocalypse, Not Now," p. 24.

4.Ibid., p. 27.

5. Ibid., p. 23.

6. Akira Mizuta Lippit, Atomic Light (Shadow Optics) (Minneapolis and London: University of Minnesota Press, 2005), pp. 30-60.

7. André Breton, "Prolegomena to a Third manifesto of Surrealism or Else", 
$V V V$, no. 1 (1942), pp.18-26. Matta selected preexisting images but also used his own drawing, "Les grandes transparentes."

8. Christian de Maussion, "Mythomattaque. Entretien avec Matta," L'Autre journal, no. 9, 1986, p. 39 .

9. “à toujours été attiré par les travaux des physiciens modernes sur la propagation des ondes et les radiations, et par les transformations gigantesques que les savants viennent de faire subir à la matière." Robert Tenger, "Note de l'éditeur," in Denis de Rougemont, Lettres sur la bombe atomique (New York: Brentano's, 1946), p.11. Translations from the French by Michael Andrews for my article "World History and Earth Art", e-flux journal, no. 49, November 2013, on which this discussion of De Rougemont is based.

10. "La belle preuve - on avait tout arrangé pour cela!" De Rougemont, Lettres sur la bombe atomique, p. 19.

While De Rougemont does not identify Duchamp by name in his 1946 book, he later confirmed his identity: see Denis de Rougemont, Journal d'une époque (1926-1946) (Paris: Gallimard, 1968), pp. 562-71.

11. In the French original: "possibilités d'union mondiale." De Rougemont, Lettres sur la bombe atomique, p. 90.

12. "À l'arme planétaire correspond donc une communauté universelle, qui relègue les nations au rang de simples provinces. Laissez-vous entraîner quelques instants dans ce jeu gravitant de symboles: la Terre, la Globe, la Boule, la Tête, la Bombe, et l'Unité considérée partout et de tout temps comme objet rond, pomme, sphère ou sceptre d'or, que ce soit l'Univers, ou l'Empire, ou l'Atome. Ici les extrêmes se reflètent." De Rougemont, Lettres sur la bombe atomique, p.110.

13. Carter Stone and Wolfgang Paalen, "During the Eclipse". In Wolfgang Paalen, Form and Sense (Problems of Contemporary Art, no. 1) (New York: Wittenborn, 1945), p. 21.

14. See Wolfgang Paalen, “The Dialectical Gospel,” Dyn, no. 2 (July/August 1942), pp.54-59. This issue also contains Paalen's famous "Inquiry on Dialectic Materialism," pp. 49-54.

15. Wolfgang Paalen, "Art and Science" (1942), Form and Sense, p. 64.

16. Wolfgang Paalen. "On the Meaning of Cubism Today" (1944), Form and Sense, p. 30.

17. Letter from Paalen to Gordon Onslow Ford, August 26 1945, quoted in Annette Leddy, "The Painting Aesthetic of Dyn," in Farewell to Surrealism: The Dyn Circle in Mexico, eds. Annette Leddy and Donna Conwell (Los Angeles: Getty Research Institute, 2012), p. 33 .

18. As Andreas Neufert puts it in his biography of Paalen: "Paalen wiederum schlug sich mit Einwänden und Skrupeln gegen Matta herum, der von Hiroshima und Nagasaki einfach gestrickte Rückschlüsse auf seine Malerei ziehen 
wollte." Neufert, Auf Liebe und Tod: Das Leben des Surrealisten Wolfgang Paalen (Berlin: Parthas, 2015), p.527. See also more in general Neufert, pp. 433ff., for a detailed account of Paalen's practice in 1945-46.

19. Wolfgang Paalen, "Brief Outline," part of the unpublished typescript of The Beam of the Balance (1946). I am grateful to Andreas Neufert for making this script available to me.

20. Paalen, Form and Sense.

21. Bartnett Newman, "The New Sense of Fate" (1948), in Selected Writings and Interviews, ed. John P. O’Neill (Berkeley and Los Angeles: University of California Press, 1990), p. 165.

22. Newman, "The New Sense of Fate," p.169

23. Georges Henein, "The Prestige of Terror" (1945), http://www.egyptiansurrealism.com/index.php?/contents/the-prestige-of-terror/

24. Henein, "The Prestige of Terror."

25. Newman, "The New Sense of Fate," p.169.

26. Kurosawa's I Live in Fear (1955) is an example of a film that addresses the social and psychological fallout of the threat (and, for Japan, the memory) of nuclear war.

27. Baj collaborated closely with Asger Jorn during the 1950; it was Baj who brought him into contact with the Lettriste Internationale, and who went on to co-organize the 1956 Alba Congress.

28. Anders, "Tagebuch aus Hiroshima und Nagasaki," p. 64.

29. "Dass diese verspätete offizielel Vorliebe für Zerstörung von Gegenstandsformen in der Kunst (bzw. die Propaganda für den Genuss an dieser Zerstörung und die Verhöhnung derer, die diesen Kunstfortschritt nicht mitmachten) mit der effektiven Zerstörung der Welt synchronisiert aufgetreten ist, war kein Zufall. Und ebensowenig ist es ein Zufall, dass die Zerstörung der Welt, für die hier in Hiroshima die Generalprobe abgehalten wurde, ihr Monument in einem 'nonobjective object' gefunden hat." Anders, "Tagebuch aus Hiroshima und Nagasaki," p.65. Author's translation.

30.Sabu Kohso, "Radiation and Revolution," www.borderlands.net.au/vol11no2_2012/kohso_radiation.pdf, p. 8 .

31. On the nuclear regime as a thanatocracy, see Michel Serres, Pantopie: De Hermès à Petite Poucette; Entretiens avec Martin Legros et Sven Ortoli (Paris: Le Pommier, 2014), pp.161-84.

32. As is evident from the title, Breton presents science as a lost cause altogether, rather than defending it against its instrumentalization, against its reduction to “Zweckvernunft." This is a symptom of Breton's progressive withdrawal into esotericism. See André Breton, Démasquez les Physiciens, videz les laboratoires! (1958), http://www.andrebreton.fr/work/5660010071969o 
33. Hans Magnus Enzensberger, "Constituents of a Theory of the Media," New Left Review, no. 64, first series (November-December 1970), p. 25.

34. Karl Marx and Friedrich Engels, The German Ideology (1845-46), Part I, https://www.marxists.org/archive/marx/works/1845/german-ideology/chola.htm

35. Terry Eagleton, The Idea of Culture (Malden, MA aand London: Blackwell, 2000), p. 10. See also Raymond Williams, Keywords: A Vocabulary of Culture and Society, rev. ed. (New York: Oxford University Press, 1983), pp. 87-93.

36. See Theodor W. Adorno, Versuch über Wagner in Die musikalischen Monographien, Gesammelte Schriften, vol. 13, ed. Rolf Tiedemann (Frankfurt am Main: Suhrkamp, 1971), pp.7-148; Matthew Wilson-Smith, From Bayreuth to Cyberspace (New York and Abingdon: Routledge, 2007).

37. Wilson-Smith, pp. 42-43.

38. Carl Andre, "Art is what we do. Culture is what is done to us" (1967), in Cuts: Texts 1959-2004, ed. James Meyer (Cambridge MA and London: MIT Press, 2005), p. 30.

39. Guy Debord, "Thèses sur la révolution culturelle," Internationale situationniste, no. 1 (June 1958), pp. 20-21; English translation by Ken Knabb at http:// www.bopsecrets.org/SI/1.cultural-revolution.htm

40. Situationist International, "Géopolitique de l'hibernation," Internationale Situationniste, no. 7 (April 1962), pp.3-10; quoted from English translation by Ken Knabb, "Geopolitics of Hibernation," at http://www.bopsecrets.org/SI/7. hibernation.htm

41. "Geopolitics of Hibernation." The first part of the Vaneigem text referenced in this quotation, "Banalités de base," also appeared in issue no. 7 of the Internationale Situationniste (pp. 32-41).

42. This critical motif plays an important role in both "Geopolitics of Hibernation" and "Basic Banalities."

43. "Geopolitics of Hibernation."

44. Guy Debord, "Les situationnistes et les nouvelles formes d'action dans la politique ou l'art" (June 1963), quoted from the English translation by Ken Knabb, "The Situationists and the New Forms of Action in Politics and Art," at http://www.bopsecrets.org/SI/newforms.htm

45. Debord, "The Situationists and the New Forms of Action in Politics and Art." 46. For an in-depth analysis of the exhibition and its various components as well as of the political and cultural context, see Mikkel Bolt Rasmussen, "To Act in Culture While Being gainst All Culture: The Situationists and the 'destruction of RSG-6'," in Expect Anything Fear Nothing: The Situationist Movement in Scandinavia and Elsewhere, eds. Mikkel Bolt Rasmussen and Jakob Jakobsen (Copenhagen: Nebula; New York: Autonomedia, 2011), pp. 75-113.

47. Debord, "The Situationists and the New Forms of Action in Politics and Art." 
48. Gustav Metzger, "Manifesto Auto-Destructive Art" (1960), in Contemporary Art: A Sourcebook of Artists' Writings, eds. Kristine Stiles and Peter Selz (Berkeleyand Los Angeles: University of California Press, 1995), pp. 401-2.

49. See Régis Debray, "Socialism: A Life-Cycle," New Left Review no. 46 (July/ August 2007), pp. 5-28.

50. Incidentally: the sinologist Vienet would later represent nuclear companies Framatome and Cogema in Taiwan; he remains convinced of the "necessity" of nuclear power. See "René Vienet: 'The Bad Boy of Sinology", http://www.notbored.org/vienet-radiofrance.html; Gérard Berréby and Raoul Vaneigem, Rien n'est fini, tour recommence (Paris: Éditions Allia, 2014), p. 126.

51. Debord, of course, balked at being described as the éminence grise of Champ Libre, but the evidence is all over his published correspondence. On Debord and Champ Libre, see also Sven Lütticken, "Guy Debord and the Cultural revolution", Grey Room, no. 52 (Summer 2013), pp.108-27.

52. Jaime Semprun, La Nucléarisation du monde (Paris: Éditions Gérard Lebovici, 1986).

53. Anonymous (Jean-Pierre Baudet), Tchernobyl. Anatomie d'un nuage (Paris: Éditions Gérard Lebovici, 1987).

54. In a letter to Debord, Baudet mentions that the book should be published quickly, as the media and the public's attention was already moving on. Thus even while in many ways following the beat of a different drummer, Champ Libre at times felt the need to intervene in current debates in a precisely timed way. This letter is missing from Debord's Correspondance, in which only Debord's own missives have been included - and from which Baudet's name has been excised altogether. See “Jean-Pierre Baudet à Guy Debord," December 29 1986, in Jean-François Martos, Correspondance avec Guy Debord (Paris: Le fin mot de l'histoire, 1998), pp. 205-7.

55. In 2002, Anders's book would finally be published in French by Éditions Ivrea and the Édition de l'Encyclopedie des nuisances. Concerning the collapse of Debord's relations with Semprun and Baudet, see the correspondence in Martos, Correspondance avec Guy Debord, pp. 245-55.

56. René Riesel and Jaime Semprun, Catastrophisme, admission du désastre et soumission durable (Paris: Éditions de l'encyclopédie des nuisances, Paris 2008).

In the 1990s, Riesel was a key player in the French Peasants' Confederation alongside José Bové. In 1998, they and a third member of Confederation were put on trial for having sabotages a first trial with Novartis's genetically modified corn. See Riesel, "Declaration Before the Tribunal of Agen," trans. Ken Knabb, http://www.notbored.org/agen.html

57. René Riesel and Jaime Semprun, Catastrophism, Disaster Management and Sustainable Submission, translated from the Spanish edition (s.l.: Roofdruk Edities, 2014), p. 42. 
58. Riesel and Semprun, Catastrophism, p.42. If this comes close to rightwing attacks on "global warming alarmism," more unsettling still is an offhand reference to an author named Kaczynski, without any acknowledgement that Kaczynski was the Unabomber. As Ken Knabb put regarding an earlier interview with Riesel: "Neither Riesel nor his interlocutor remind the reader that, as the 'Unabomber,' Theodore Kaczynski was a terrorist, and that his sexist and homophobic 'manifesto' was only published because, in exchange, he promised to stop attempting to maim and kill people." See "The progress of submission moves at a frightening speed. An interview with Rene Riesel," http://www.notbored.org/riesel-interview.html\#_ednref11

59. Adorno, Versuch über Wagner, p. 97.

6o. Riesel and Semprun, Catastrophism, p.12.

61. The Realists [Henry Flynt], "Overthrow the Human Race!", Happening \& Fluxus, ed. H. Sohm (Cologne: Kölnischer Kunstverein 1970), unpaginated; see also Branden W. Joseph, Beyond the Dream Syndicate: Tony Conrad and the Arts after Cage (New York: Zone Books, 2008), pp. 210, 419 (note 135). Joseph notes that Flynt founded his "party," The Realists, in 1968, and dates the "Overthrow" manifesto as "ca. 1969."

62. Leslie A. Fiedler. "The New Mutants", Partisan Review 43, no. 4 (Fall 1965), pp. 505-25.

63. Situationist International, "Révolte et récupération en Hollande", Internationale Situationniste, no. 11 (October 1967), pp. 65-66.

64. Roel van Duyn, Energieboekje: over de energie-krisis en de oplossing daarvan door een alternatieve technologie (The Hague: Bert Bakker, 1972).

65. "Weesp testgebied voor Philips-Duphars Zenuwgassen", De Paniekzaaier, no. 1 (November 1971), p. 6. Author's translation.

66. Semprun, La Nucléarisation du monde, pp.14, 38. Translation from Semprun by the author.

67. Riesel and Semprun, Catastrophism, p. 21.

68. Riesel and Semprun, Catastrophism, p.22.

69. Sempun, La Nucléarisation du monde, p. 30.

70. Kodwo Eshun, remark during a seminar with research master's students at Casco, Utrecht, autumn 2014.

71. Semprun, La Nucléarisation du monde, p. 39.

72. Stewart Martin, "The Absolute Artwork Meets the Absolute Commodity", Radical Philosophy, no. 146 (November/December 2007), p. 22.

73. www.dontfollowthewind.info

74. By contrast, Aernout Mik's 2013 video installation Cardboard Walls appeared to do everything to distance the reality of the Fukushima fallout from the (European) viewer. Mik treated the disaster as yet another occasion for staging Mikkian 
Apocalypse (Not) Now

scenes, though livened up with a hint of exoticism: while homing in on Japanese ritual of public apology and self-humiliation, Mik otherwise created a generic theatre of the absurd, with shell-shocked and displaced people sitting and lying around between makeshift cardboard walls. The absence of sound added to Mik's distinctly non-Brechtian distantiation effect, which removed the scene into a timeless sphere of mock-existentialist aesthetics.

75. See for instance http://www.independent.co.uk/arts-entertainment/art/ news/frieze-visitors-queue-up-to-risk-delicious-yet-possibly-toxic-fukushimaradish-soup-9801420.html

76. See the video documentation at

https://www.youtube.com/watch?v=vvQUCaDAtjU 